\title{
The Future of Tobacco Industry Amidst of COVID-19 -A Case of Malawi Producing Country
}

\author{
George N Chidimbah Munthalii ${ }^{1}$ and Wu Xuelian ${ }^{2,3 *}$ \\ ${ }^{1}$ Yangtze University-School of Economics and Management, P.R. China \\ ${ }^{2}$ Mzuzu University Private Bag 201, Luwinga, Mzuzu, Malawi \\ ${ }^{3}$ Chidimbah Financial Consults P.O Box 20013, Luwinga, Mzuzu, Malawi \\ *Corresponding author: Wu Xuelian, Yangtze University-School of Economics and Management, Nanhuan Road, Jingzhou, Hubei, \\ P.R. China, Email: wuxuelian@yangtzeu.edu.cn
}

ORCID: https://orcid.org/0000-0002-1513-7312

\section{ARTICLE INFO}

Received: 慧 May 01, 2020

Published: 幽 May 22, 2020

Citation: George N Chidimbah Munthali, Wu Xuelian. The Future of Tobacco Industry Amidst of COVID-19 -A Case of Malawi Producing Country. Biomed J Sci \& Tech Res 27(5)-2020. BJSTR. MS.ID.004566.

Abbreviations: NGO: Non-Governmental Organization; CAGR: Compound Annual Growth Rate; TCC: Tobacco Control Commission; AHL: Action Holdings Limited; TAMA: Tobacco Association of Malawi; HRDC: Human Rights Defenders Ciliation; WHO: World Health Organization

\section{Abstract}

With outbreak of COVID-19 last year in Wuhan China, the Virus has affected almost all parts of the world and all business industries and sectors of development. Tobacco industry is also affected much due to its healthy problems associated with the consumption of tobacco like corona lung disease and cancers that are linked to have high risks to contact COVID-19. This paper was conducted with an aim to highlight the future of tobacco industry by gathering available data from online and reporting from it. This paper has highlighted that despite being a well-established industry in the world that has been contributing economically to many countries, the aftermath of COVID-19 will have a big negative impact on the industry as many international health organizations like World Health Organization, environmental organizations and human rights activist organization will increase the existing pressure to the industry in order to reduce the production and consumption of tobacco related products which will also have a negative effect on the industry of tobacco. Its recommended that economies and companies that depend on tobacco should also start looking at other options of diversification which in future may replace total dependence on tobacco which its future is not certain.

Keywords: COVID-19; Tobacco Industry; Malawi Tobacco Industry; Tobacco and heath

\section{Introduction}

COVID-19 Virus which first started in Wuhan, Hubei Province in the Peoples Republic of China last year and later declared as a pandemic by the World Health Organization on 11 March has created the whole world in a surge as it has infected, killed and put on stand still a lot of the people and business from all over the whole World [1-4]. In attempts to stop the spread of the virus and the death rates social distance measures have been put in place in many different countries across the globe which have effective impacts and has also negatively affect the way the people used to do their daily activities by restricting gathering and movements of people on where business and other economic activities were being conducted [5-7]. The impact of the COVID-19 has not left the tobacco industry which is also currently facing many challenges as the majority of the producing and buying Countries are also affected. Tobacco Industry has been a vigorous industry which has received both positive and negative comments from the world depending from which side the commenters looks at, this is so because tobacco has been one of the main source of employment, GDP and economic development on many countries for decades however it is also the main cause of health problems which has led to many deaths among people in the world $[8,9]$. This perspective was aimed at highlighting the future of tobacco industry in the world in amidst of the outbreak of COVID-19 by reviewing available published studies and other online data, lastly the pathway and recommendation was given by taking into accounting of a sub-Saharan producing country of Malawi. 


\section{Theoretical Framework}

\section{Dependent Variable}

This perspective conceptualized tobacco industry as a dependent variable. For the purpose of this study tobacco industry includes all chain of players that are involved in converting raw tobacco from starting from tobacco farming, buying processing, marketing, selling companies and lastly the consumers that use tobacco end product $[10,11]$.

\section{Independent Variable}

For the purpose of this perspective we conceptualized COVID-19 as Independent Variable, COVID-19 is defined as an infectious Pathogen Zoonotic disease that is caused by Severe Acute Respiratory Syndrome Coronavirus $2[12,13]$.

\section{Other Variables}

Non-Governmental Organization (NGO) and Government have been conceptualized as other variables like Heath Organization like WHO, Human rights activists and environmental protectionist groups are regarded as non-controlled variables. We conceptualized all organization that act in protecting human health through campaigns of stopping smoking tobacco and other users, protection the environment through stopping cutting down the trees and use of chemicals which are used in tobacco farming and lastly those that protect vulnerable people like children that working farms and women that are mistreated to be under these three variables,

\section{Methods}

In order to write a good perspective study that would achieve its aim and give the readers the clear understanding on the subject matter, we followed a well systematic method of collecting data.
Data was gathered from the internet from the month of April 2020, published peer reviewed and other data sources were collected from the search engines of, Google Scholar, ResearchGate, Web of Science, University Websites and Organization official websites. The strings used to search data were, COVID-19, Tobacco industry, Malawi tobacco system, Tobacco and health. In order to get up to date data the time frame used was from 2000-2020 only with location form the whole world to have an in-depth knowledge of the data.

\section{Results and Discussion}

\section{Global Tobacco Industry}

Tobacco has long history dated back five century ago attached to pre- Colombian Americans, Christopher Columbus being among the people that are well known of using it and firstly being introduced in Africa in the late 1560 [14]. There are many varieties of tobacco that are being farmed in the world with major ones being Burley, Maryland, Oriental, Dark-fired and Flue -cured, which are being used as a raw material for many products with majority percentage used for the manufacture of the pipes, cigars and cigarettes for smoking and other chewing $[10,15]$. Some of the major tobacco growing countries for the decades have been China, Brazil, Indonesia, Zimbabwe, Malawi, Argentina, Turkey, India, Pakistan, Tanzania, Zambia etc. $[11,16]$. Throughout these decades tobacco industry has been seen as one of the well-established industries in the world which has been contributing positively to developments of many economies through the economic value attached to the chain market like the creation of the employment to a lot of people and the product itself when its sold and processed product, having an approximately of USD 694.47 Billion with Compound Annual Growth Rate (CAGR) of 2.8\% by $2021[17,18]$ ( Figure 1).

\section{Global tobacco market size, 2012 - 2021 (USD Billion)}

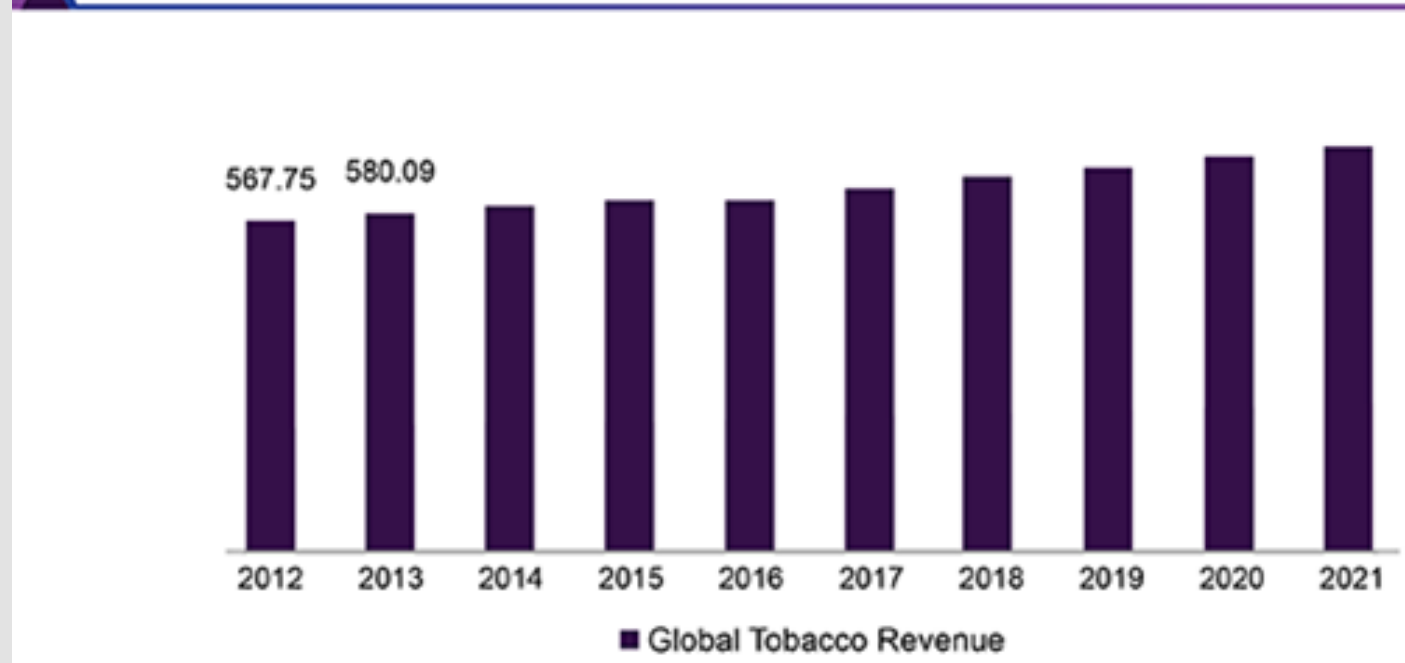

Figure 1: Showing Growth of Global Tobacco Market.

*Source: (GRR 2018). 
The leading tobacco companies worldwide that have been making a lot of sales in billions USD in the year 2019 in the tobacco industry are British American Tobacco, Phillip Morris International, Imperial Brands, Japan Tobacco, Altria Group, ITC, Gudang Caram, KT\&C etc. [19] (Figure 2). However, having these positive economic benefits, the tobacco industry through its products like cigarettes has also brough in a lot of negative impacts through healthy problems like cancer, corona heart diseases, Asthma etc., environmental degradation through the use of chemicals fertilizer, pesticides and cutting of the tress for fire cured tobacco, social problems through child labour in many tobacco cultivating estates and women violence's and injustices [20-23]. Due to awareness campaigns and restrictions by heath international organizations championed why WHO by emphasizing the negatives impacts that tobacco industry has on human beings, the industry has been facing a lot challenges which could have seen its collapse [9,24], but due to its nicotine addictions, the market elasticity of demand for tobacco has not been responding to these calls especially from the consumers side, furthermore, they have been inconsistences and varying in many economies on these calls to reduce the production and consumption of tobacco with just a small reduction when tax measures were used as compared to civic educations [25-27].

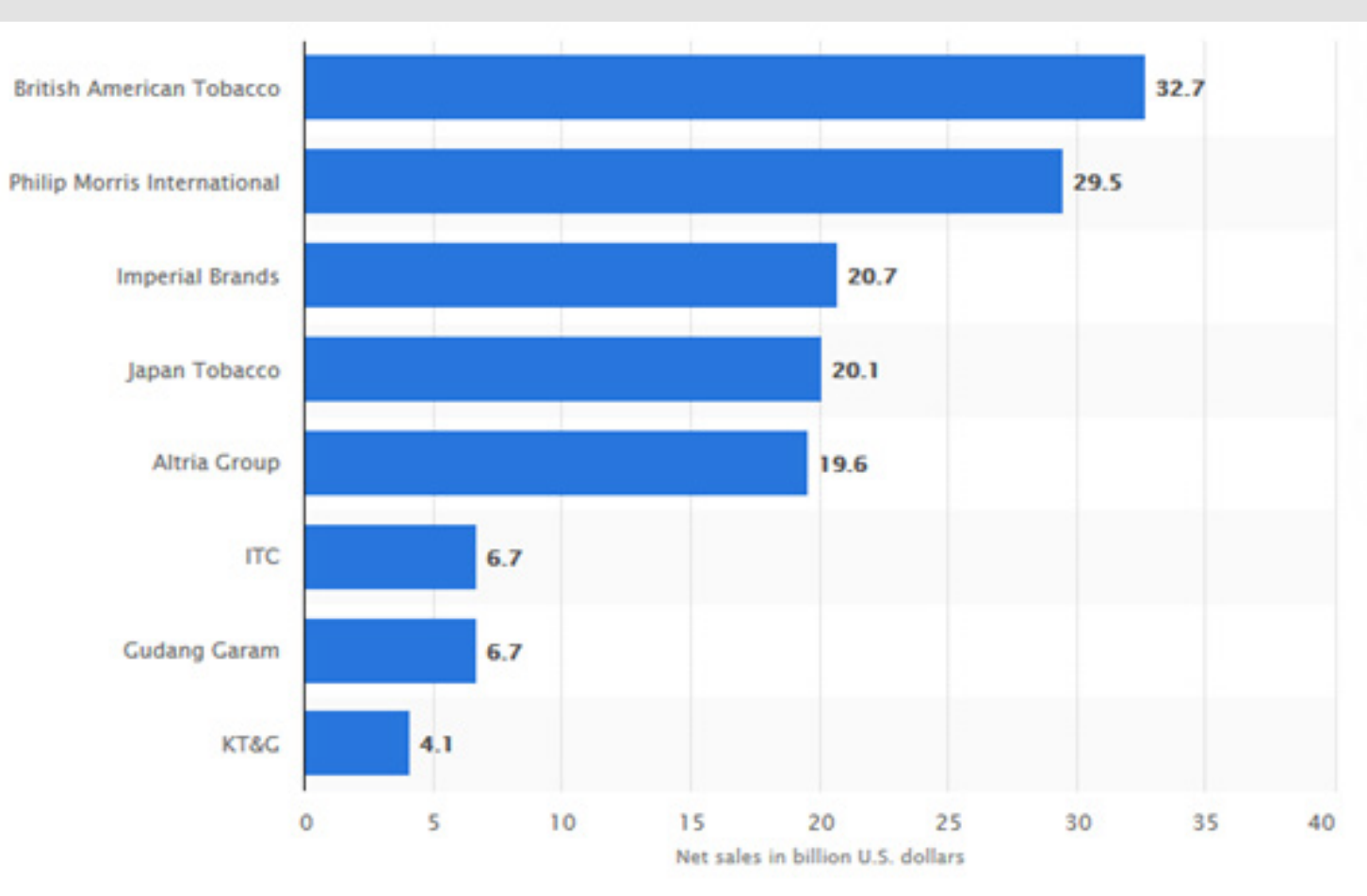

Figure 2: Showing leading Tobacco Companies Worldwide in 2019 based on Net Sales (Billion USD). *Source: (Jan Conway 2020).

\section{Malawi Tobacco Industry}

Ranking among least developing countries in the world, Malawi previously known as Nyasaland is one among of the sub-Saharan countries sharing borders with Zambia, Tanzania and Mozambique that mostly depend on agriculture for the GDP , Tax and Forex [28], Malawi has been for the past years listed among the top 10 Countries in the world and one of the top African country in exporting burley tobacco, Malawian tobacco is known for its quality which has attracted world market [29,30]. The tobacco industry in Malawi is also traced back since 1893 [31], since then, the industry in Malawi has been well established with some of main players being, the famers themselves that are responsible for cultivating the tobacco, Tobacco Control Commission (TCC) which is acts as a regulatory body for volumes and registration of quoters , Action Holdings Limited (AHL) which offers the markets for the buyers,
Tobacco Association of Malawi (TAMA) which promotes and acts in the interest of the famers, Leaf Buying Companies like Alliance One, Limbe Leaf, Premium Tama, the Ministry of Agriculture that act as regulatory body too, etc. [32].

There is a big debate among people in Malawi as to whom the industry has benefited more, as some studies have found that the tobacco industry in Malawi just like other industries in other counties has benefited few individuals especially those linked to political powers, buying companies, and farm owners rather than rural famers who do the ground work, as a results people have been living in continues poverty lines despite farming tobacco for many years without any significant changes to their lives [11,29,32,33]. The tobacco market in Malawi usually starts from the month of March to September each year depending on that year rainfall, number of bales received at the auctions and other factors that 
the stakeholders like the government, TCC, AHL, TAMA etc. may consider and agreed upon [34,35], despite COVID-19 outbreak and the existence of some social distances measures within the country, Malawi as a nation has joined other countries like Zimbabwe [36], to announce the opening of the 2020 tobacco season, the Tobacco Control Commission that is responsible for making announcement on sale of Tobacco in Malawi announced the opening of the market which started on $20^{\text {th }}$ April at Lilongwe selling floors, Chinkhoma selling floors on $22^{\text {nd }}$ April, Limbe selling floors on $27^{\text {th }}$ April and Mzuzu selling floors $04^{\text {th }}$ May 2020 [37] with taking into account serious preventative measures of COVID-19 like wearing masks and putting bales at distances in the auction.

However the future of the tobacco market is still under questionable as the country continues to register COVID-19 new cases each and every day which may prompt authorities for possible lockdowns as proposed earlier by the government which were put on hold due to court injunction obtained by the Human Rights Defenders Ciliation (HRDC) $[4,38,39]$. Looking into the current economic status of Malawi which depends mainly on agriculture products with tobacco giving its high percentage its very clear that the delay and the future consequences of COVID-19 which will affect the whole world will also be a heavy blow on Malawi economy to recover since its already a struggling economy which was in the process of improving [40,41]. Experts in tobacco industry in Malawi has also already forecasted about $6.62 \%$ a reduction of volumes in tobacco this season due to factors like heavy rains and coming out of other farmers out of the industry with unsatisfactory last year's prices [42] (Figure 3).

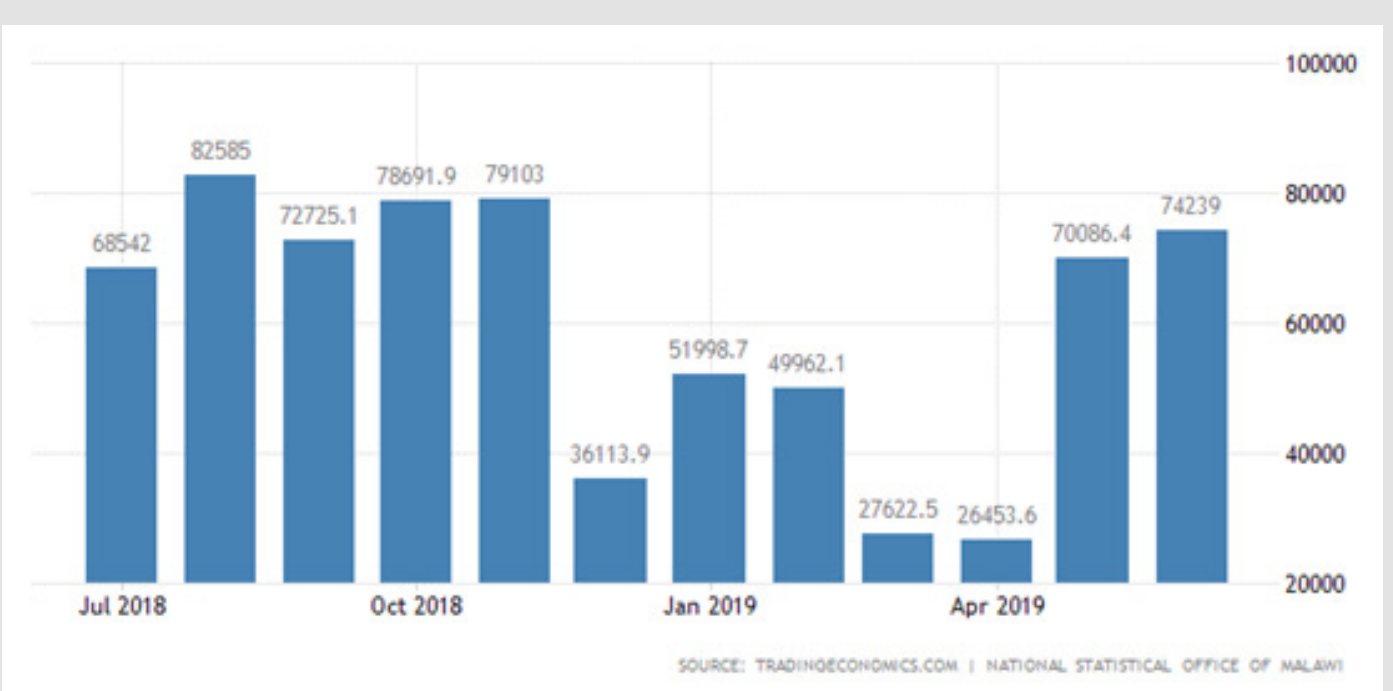

Figure 3: Showing Malawi Exports increases.

*Source: (Economics 2020).

\section{Future of Tobacco Industry}

As it has been highlighted from this perspective that despite having economics benefits, tobacco industry recently has been facing many challenges from health organization like the World health Organization (WHO) due to its healthy problems that are caused through smoking [24], environmental protectionist groups due to negative environmental impacts by cultivations during tobacco curing, human rights activists group due to its social problems through child labour and women mistreatments $[17,43]$. There is evidence that tobacco through smoking cigarettes has caused death to more than 6 million people in the whole world and its furthermore estimated that more deaths are to be registered by 2030 where by making the WHO declaring it as an epidemic and calling upon all governments to implement necessary measures to reduce the consumptions of tobacco $[24,44]$, most of the healthy problems associated with the cigarettes smoking are lung cancers, reproductive health problems, Coronary heart diseases, nasal irritation ,Asthma etc. [16].
Furthermore, Current studies have found and reported that people with underlying heathy conditions like of hearts disease, diabetes, lung diseases are more prone to COVID-19 than those that are not $[2,45,46]$. This clearly indicates that they is high risks associated with people that smoke and consume tobacco which may bring to them these underlaying healthy conditions that may be easily make them vulnerable to contact the Virus $[9,44,47]$. Therefore, the aftermath of the COVID-19 will have a negative impact on the tobacco industry as health organizations like WHO, other Non-Governmental Organization (NGO) and even government authorities will be pressing more and more pressure in the reduction of the production and consumption of the tobacco related products in the world which at the end will have a negative impact to the tobacco industry, as many people may also be voluntarily stopping to smoke due to fear which the COVID-19 has brought to the whole world. However, we cannot rule out the fact of the addictions and elasticity that the tobacco industry is attached to which will also in the other way help the industry to keep struggling regardless of the pressure which will be put on it. 


\section{Recommendations}

Its therefore recommended that countries and companies that depends mainly on tobacco as a sole main activities to further consider other cash crops and ways of diversification in their industry respectively, which may be introduced to replace tobacco which has been their cash crops and sole product for many years, however this will be a difficult task upon looking at the way the industry is established, but the policy makers should also look at the cost benefit analysis before making this hard decision as a lot funds are also diverted to cater for the cost which comes with tobacco consumption. Furthermore, as COVID-19 has changed the mindset of people and the way things are to be done in the future, it should also act as a wakeup call to the tobacco industry that in the near future there will be a possibility that the consumption of tobacco will be completely banned by mutual agreements from different stakeholders, also by voluntary discard by the users as everyone currently has been witnessing the impact of COVID-19 and would not again be associated with any level of risk to contact it or in the future other infectious diseases that may come and cause havoc more than COVID-19.

\section{Conclusion}

In conclusion, Countries and tobacco companies should be well prepared for the reduction in their revenues which will happen due to the effect of the COVID-19, as such well-planned measures should be thought in advance on how the economies may recover fast especially those countries that they depend on tobacco as their main source of GDP like Malawi.

\section{Conflict of Interest}

The authors declare that there is not any conflict of interest.

\section{Funding}

This study did not receive any funding form anyone or any organization.

\section{Acknowledgement}

The authors acknowledge the Journal Editorial team for their remarkable support and work rendered during the production of this article, furthermore we acknowledge Yangtze University School of Economics and Management for their continuation support. Lastly, we thank Gama Rivas Daru for his support when we were writing this paper.

\section{References}

1. Salzberger B, Glück T, Ehrenstein B (2020) Successful containment of COVID-19: the WHO-Report on the COVID-19 outbreak in China. Infection 48: 151-153.

2. (2020) WHO, Report of the WHO-China Joint Mission on Coronavirus Disease 2019 (COVID-19). WHO p. 16-24.

3. (2007) WHO Interim Guidelines. Infect Prev Control epidemicpandemic-prone acute Respir Dis Heal care p. 1-90.

4. Munthali GNC, Xuelian W (2020) Covid-19 Outbreak on Malawi Perspective. Modestum 17(4): 17-19.
5. Singh R, Adhikari R (2020) Age-structured impact of social distancing on the COVID-19 epidemic in India.

6. Zhang Y, Jiang B, Yuan J, Tao Y (2020) The impact of social distancing and epicenter lockdown on the COVID-19 epidemic in mainland China: A data-driven SEIQR model study. medRxiv.

7. Roy S (2020) COVID-19 pandemic: Impact of lockdown, contact and noncontact transmissions on infection dynamics. medRxiv.

8. Goma F, Drope J, Zulu MR, Li MQ, Chelwa G, et al. (2017) The Economics of tobacco farming in Zambia.

9. Walsh DRA, Sanson Fisher PRW (2001) Encouraging stopping smoking. Depend World Heal Organization p. 1-58.

10. (2020) Tobacco Farming and Curing. PMI - Philip Morris International [Internet]. PMI.

11. Influences 0, Products T. Chapter 10 Tobacco Growing and Tobacco Product Manufacturing. Econ Tob grow Tob Control.

12. WHO (2019) Coronavirus disease (COVID-19) pandemic. WHO.

13. Fahmi I (2020) Covid19 Coronavirus Disease 2019. DroneEmprit.

14. Oluwafemi A (2003) Regional summary for the African region. Tob Control Ctry Profiles p. 27-31.

15. Davies P (2003) Malawi: Addicted to the leaf. Tob Control 12(1): 91-93.

16. Drope, Schluger, Cahn, Drope, Hamill, (2018) The Tobacco Atlas. Atlanta: American Cancer Society and Vital Strategies [Internet]. Word Lung p. $22-34$

17. (2013) WHO, Tobacco companies spend tens of billions of dollars each year on tobacco advertising, promotion and sponsorship p. 11-201.

18. (2020) Tobacco Market Size Worth \$1.08 Trillion By 2027 | CAGR: 3.1\%.

19. Jan Conway (2020) Leading tobacco companies worldwide in 2019 , based on net sales.

20. (2017) Problem THE, Child OF, Agriculture In. Eliminating child labour in tobacco-growing communities the problem of child labour.

21. (2020) Child Labor and Tobacco Farming: Are Kids Adequately Protected? Here \& Now.

22. (2013) Southeast Asia Tobacco Control Association. Child Labour in Tobacco Cultivation in the ASEAN Region.

23. Hu TW, Lee AH (2016) Women in tobacco farming: Health, equality, and empowerment A study conducted in China, Tanzania and Kenya. Public Health Institute p. 1-50.

24. Asamblea Mundial de la Salud (2003) WHO framework convention on tobacco control. Rev Esp Salud Publica 77(4): 475-505.

25. Čizmović M, Laković T, Popović M, Mugoša A (2018) The elasticity of tobacco products.

26. Adeniji F (2019) Consumption function and price elasticity of tobacco demand in Nigeria. Tob Prev Cessat 5: 48.

27. World Health Organization (WHO) Estimating price and income elasticity of demand Introduction. WHO.

28. (2020) Malawi GDP - composition by sector - Economy. Index Mundi.

29. Otañez MG, Mamudu H, Glantz SA (2007) Global leaf companies control the tobacco market in Malawi. Tob Control 16(4): 261-269.

30. Kulik MC, Bialous SA, Munthali S, Max W (2017) Tobacco growing and the sustainable development goals, Malawi. Bull World Health Organ 95(5): 362-367.

31. Muhome Matita M, Chirwa EW (2011) Agricultural Growth and Poverty in Rural Malawi.

32. Drope J, Makoka D, Lencucha R, Appau A (2016) Farm-level economics of tobacco production in Malawi. 
33. Mdee A, Ofori A, Chasukwa M, Manda S (2020) Neither sustainable nor inclusive: a political economy of agricultural policy and livelihoods in Malawi, Tanzania and Zambia. J Peasant Stud p. 1-24.

34. (2020) The Tobacco Commission.

35. (2020) AHL Group - Tanzania President Opens 2019 Malawi Tobacco Market.

36. Marawanyika G, Kumbuka D (2020) Zimbabwe's Tobacco Auction to Start April 29 After Virus Delay. Bloomberg.

37. (2020) TCC-Pess Release. Press Release - Opening of 2020 Tobacco Marketing Season.pdf.

38. (2020) Court stops Malawi lockdown, Judge Kenyatta grants HRDC injunction: New Covid-19 case registered - Malawi Nyasa Times.

39. (2020) COVID-19 National Information Dashboard. MOHM.

40. Brahmbhatt M, Dutta A (2008) On SARS Type Economic Effects during Outbreaks of Infectious Disease. World Bank Res Dig p. 1-24.

ISSN: 2574-1241

DOI: 10.26717/BJSTR.2020.27.004566

Wu Xuelian. Biomed J Sci \& Tech Res

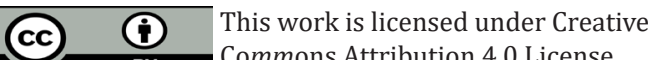

Submission Link: https://biomedres.us/submit-manuscript.php
41. Bloom DE, Cadarette D, Sevilla JP. New and resurgent infectious diseases can have far-reaching economic repercussions. Finance Dev 55(2): 4649.

42. (2020) Malawi registers 6.62\% decline in tobacco production - Malawi Nyasa Times - News from Malawi about Malawi [Internet]. Nyasatimes.

43. Hefler M, Gartner CE (2020) The tobacco industry in the time of COVID-19: time to shut it down? Tob Control 29(3): 245-246.

44. Vardavas C, Nikitara K (2020) COVID-19 and smoking: A systematic review of the evidence. Tob Induc Dis 18: 20.

45. Velavan TP, Meyer CG (2020) The COVID-19 epidemic. Trop Med Int Heal 25(3): 278-280

46. Mariana N (2020) Coronavirus disease 2019 ( COVID-19).

47. Doe J, De Santo C (2009) Smoking's immediate effects on the body. Tobacco-Free Kids p. 1-9.

\begin{tabular}{ll} 
BIOMEDICAL & Assets of Publishing with us \\
RESEARCHES & - Global archiving of articles \\
& - Immediate, unrestricted online access \\
\hline ISSN: $2574-1241$ & - Rigorous Peer Review Process \\
&
\end{tabular}

